УДК 811.112

DOI https://doi.org/10.26661/2414-9594-2021-1-22

\title{
ЛІТЕРАТУРНА НОРМА Й МОВЛЕННЕВА ЕКСПРЕСІЯ В ПОЕТИЦІ В. А. ЧАБАНЕНКА
}

\author{
Сірик С. В. \\ кандидат філологічних наук, доиент, \\ викладач ииклової комісії гуманітарної та сочіально-економічної підготовки \\ Медичний фаховий коледж \\ Запорізького державного медичного університету \\ вул. Космічна, 2-В, Запоріжжя, Україна \\ orcid.org/0000-0001-9287-0094 \\ siryk.svitlana66@gmail.com
}

\begin{abstract}
Ключові слова: варіативність слова, стилістичне відхилення від норми, експресивні явищуа, експресивний потенціал, ідіостиль.
\end{abstract}

Стаття продовжує цикл публікацій, присвячених поетичній мовотворчості вченого та письменника В. Чабаненка, його новаторству в пошуку незвичних форм, образів, умінню експериментувати з поетичною мовою, розширенню словесної палітри завдяки виражально-зображальним, експресивним засобам української мови. У статті зроблено спробу аналізу мовленнєвої експресії в мовно-художній системі В. Чабаненка, яка виникає на основі свідомого стилістично заданого відхилення автора від літературної норми, з'ясування експресивного потенціалу цих одиниць. Стилістичним колоритом відзначаються експресивні явища, які виникають на грунті порушення лексичних норм, що виявляється у вживанні просторіч, говіркових слів, корпоративного жаргону, сполучуваності слів. Активно використовує автор і потужний арсенал фразеології. Він вдається до трансформації, контамінації та нагнітання фразеологічних одиниць. Експресивні явища на грунті порушення словотвірних норм виникають під час уживання автором оказіоналізмів-новотворів, серед яких переважають семантико-дериваційні оказіоналізми, утворені за допомогою пестливо-зменшувальних суфіксів від слів, що нормативно не піддаються афективності. Експресивні явища, що виникають на грунті фонетичних / фонетико-орфоепічних норм сучасної літературної мови, у мовотворчості В. Чабаненка нечисленні. Експресивні явища на грунті морфологічних норм спостерігаються лише в категоріях іменника. Мовна експресія, що створюється автором на грунті порушення синтаксичних норм, виникає в разі вживання ампліфікаційно-багатоступінчастої прикладки та повторення службових частин мови та вигука.

Естетична картина світу поета В. Чабаненка - це вдале поєднання національного образного світобачення й філософського осмислення історичного процесу. Мовні засоби, залучені автором до творення образів ліричних творів, виявляють величезні потенції загальнонародної мови та неабиякі творчі можливості митця.

Досліджені стилістично вправні відступи від загальноприйнятих норм свідчать про мовну віртуозність автора, а манера їх використання накладає відбиток на його індивідуальний стиль, якому притаманні палкий патріотизм, глибока пошана до людини праці. 


\title{
LITERARY NORM AND SPEECH EXPRESSION IN THE POETICS OF V. A. CHABANENKA
}

\author{
Siryk S. V. \\ Candidate of Philology, Associate Professor, \\ Lecturer at the Cycle Commission of Humanitarian and Socio-economic Training \\ Medical Professional College \\ of Zaporizhzhia State Medical University \\ Kosmichna str., 2-V, Zaporizhzhia, Ukraine \\ orcid.org/0000-0001-9287-0094 \\ siryk.svitlana66@gmail.com
}

Key words: word variability, stylistic deviation from norm, expressive phenomena, expressive potential, idiostyle.
The article continues the series of publications devoted to the poetic language of the scientist and writer V. Chabanenko, his innovation in finding unusual forms, images, the ability to experiment with poetic language, expanding the verbal palette through expressive, expressive means of the Ukrainian language. The article attempts to analyze speech expression in the V. Chabanenko linguistic and artistic system, which arises on the basis of conscious stylistically determined deviation of the author from the literary norm, to find out the expressive potential of these units.

Stylistic colors are marked by the expressive phenomena that arise on the basis of violations of lexical norms, which is manifested in the use of words, spoken words, corporate jargon, word combinability. Actively uses the author and a powerful arsenal of phraseology. It resorts to the transformation, contamination and discharge of phraseological units. Expressive phenomena on the basis of violations of word-forming norms arise when the author uses the oasiscreation-innovations, among which are dominated by semantic-derivational ocasisionalisms, formed with the help of affectionately-affirmative suffixes from words that are not normative to affectiveness. Expressive phenomena arising on the basis of the phonetic (phonetic-orthoepic) norms of modern literary language in V. Chabanenko's speech-making are few. Expressive phenomena based on morphological norms are observed only in the noun category. The language expression created by the author on the basis of violation of syntactic norms occurs when the amplification-multistage application and the repetition of service parts of speech and exclamation.

The aesthetic picture of the world of the poet V. Chabanenko is a successful combination of the national figurative worldview and philosophical comprehension of the historical process. Stylistically skilful deviations from the generally accepted norms testify to the linguistic virtuosity of the author, and the manner of their use leaves an imprint on his idiosyncrasy, which is characterized by ardent patriotism and deep respect for the man of labor.

The aesthetic picture of the world of the poet V. Chabanenko is a successful combination of the national figurative worldview and philosophical comprehension of the historical process. The linguistic means involved by the author in the creation of images of lyrical works reveal the huge potentials of the national language and the remarkable creative potential of the artist.

The studied stylistically skilful deviations from the generally accepted norms testify to the author's linguistic virtuosity, and the manner of their use leaves an imprint on his individual style, which is characterized by ardent patriotism, deep respect for the man of labor. 
Стаття продовжує цикл публікацій, присвячених поетичній мовотворчості вченого та письменника В. Чабаненка, його новаторству в пошуку незвичних форм, образів, умінню експериментувати 3 поетичною мовою, розширенню словесної палітри завдяки виражально-зображальним, експресивним засобам української мови. Хоча лінгвопрактика В. Чабаненка була об' єктом дослідження (наукові статті С. Кіраль «Питання теорії і практики перекладу в епістолярній спадщині І. Денисюка, Г. Кочура, В. Чабаненка», Г. Микитів «Вербалізація концепту Нижньої Наддніпрянщини в поезії В.А. Чабаненка»), однак обрана тема $є$ актуальною. Адже дослідження мови творів, вивчення специфічних рис дозволяє доповнити вже наявні уявлення про особистість митця, збагнути проблематику його творів та творчого задуму.

Метою статті $\epsilon$ виявлення й аналіз особливостей поетичного ідіостилю відомого мовознавця та поета В. Чабаненка, зокрема дослідження експресивності, яка виникає на основі свідомого стилістично заданого відхилення автора від літературної норми, з'ясування експресивного потенціалу цих одиниць. Основним об'єктом вивчення ідіостилю поета $є$ мова його ліричних творів. Саме вона $\epsilon$ реалізацією авторської моделі світу. Дослідження ідіостилю В. Чабаненка дасть можливість визначити індивідуальну неповторність, встановити його вербально-естетичну картину світу, оцінити його внесок у систему вже закріплених словесних художніх образів національної мови.

Лінгвостилістичний аспект визначеної проблеми експресії мовних засобів деталізовано в роботах І. Бацій («Краса і сила слова»), К. Горбачевича («Вариативность слова и языковая норма»), П. Дудика («Синтаксис сучасного українського розмовного і літературного мовлення»), С. Єрмоленко («Нариси з української словесності: стилістика та культура мови»), О. Пономарів («Стилістика сучасної української мови»), В. Русанівського («Естетика художнього слова»), грунтовно досліджено в науковій праці В. Чабаненка «Стилістика експресивних засобів української мови».

Тому цікаво побувати у творчій лабораторії відомого мовознавця та спробувати дослідити його новаторство в пошуку незвичних форм та образів, розширення словесної палітри завдяки мовленнєвій експресії, що виникає на основі свідомого відхилення автора від літературної норми.

Дослідження поетичної мови В. Чабаненка 3 погляду мовної норми та мовленнєвої експресії дозволяє говорити про те, що використання поетом відхилень від літературних норм є джерелом виникнення в його поезії багатьох експресивних явищ. Експресія на основі свідомого стилістично заданого відхилення автора від лексичних, фразеологічних, дериваційних, фонетичних, морфоло- гічних та синтаксичних норм $€$ характерною ознакою ідіостилю В. Чабаненка.

Відхилення від лексичних норм зі стилістичною метою виявляється у віртуозному вживанні автором ненормативної лексики (говіркові, просторічні слова, жаргонізми, оказіоналізми).

Досить часто В. Чабаненко вживає діалектне слово «ожиєм», характерне для ідіостилю I. Франка, якого поет уважав своїм духовним батьком: А ми на зло сатрапам ожиєм! [8, с. 34]1․ Уведене в літературне мовлення, говіркове слово увиразнюється, бо $є$ контрастним щодо свого нормативного оточення.

Проаналізований поетичний матеріал дозволяє відзначити активне вживання просторічної лексики. В. Чабаненко в науковій праці «Стилістика експресивних засобів української мови» зазначає: «<...> Просторіччя - це окремий стиль, у структурному відношенні слабо організований різновид усної форми загальнонародної мови, який займає проміжне місце між діалектними стилями й усними стилями кодифікованої літературної мови» $[9, \text { с. } 96]^{2}$.

Просторічній лексиці властива внутрішня експресивність, яка, потрапляючи в контекст із непросторічними нормами, на грунті контрасту набуває ще і вторинної, зовнішньої експресивності: Горить покарою Звізда Полин <... $>$ [8, с. 1-2]; земля схороня [8, с. 15]; Обнявся з тайною $[8$, с. 8]; Ув одіж чисту приберися [8, с. 24]; Довіртеся іншій судьбі! [8, с. 28].

Просторічні слова, що в більшості $є$ яскравими синонімами до літературних слів, уживаються автором і для передачі іронії, зневаги, презирства, різкого осуду, брутальності: Світ закрили нам ваші пуза! [8, с. 24]; Всміхайсь частіш, щоб не дали Культурно враз по пиці! [8, с. 34]; Пощезне $i$ підбрехачів бридня [8 с. 35]; Та в «народні слуги» Так усі й претесь <... $[8$, с. 36].

«Для сучасної української лінгвальної дійсності характерними є два різновиди жаргонів: професійні жаргони i жаргони корпоративні» $[9$, с. 100]. 3 метою змалювання совєтської дійсності та її оцінки В. Чабаненко використовує другий різновид жаргонів: Удовольнились, хохмачі [8, с. 33]; Перед торбешником не гнись! [8, с. 34]; А ми вас всіх надуємо, надуємо <...> Ми - орги, зами, поми < .. > [8, с. 38].

Надзвичайно експресивними є авторські неологізми, якими щедро всіяна поезія В. Чабаненка: У холод жил пустили трути-гною [8, с. 3]; $3 a$ ними рай і світлочари [8, с. 4]; Й розлився на півсвіту мутнохвиллям <..> [8, с. 7]; Ходи, як песик-цюця [8, с. 34].

\footnotetext{
${ }^{1}$ Цитовано за виданням: Чабаненко В. Січ духовна. Поезії. Запоріжжя, 2007. 220 с

${ }^{2}$ Чабаненко В. Стилістика експресивних засобів української мови : монографія. Запоріжжя : ЗДУ, 2002. $351 \mathrm{c.}$
} 
Улюбленим прийомом автора $\epsilon$ створення лінгвостилістичного ефекту завдяки сполучуваності слів. У пошуках нових епітетів, метафор відомий мовознавець віддає перевагу оказіональним, індивідуально-авторським словосполученням. Така сполучуваність породжує стилістично потужну метафору. Найулюбленіша модель «ім. + прикм.»: Під твою сонцекрасну калину $<\ldots>$ [8, с. 2]; Тут Первоназваний Андрій [8, с. 3]; Суиіллю стала дико-кам'яною [8, с. 3]; I велич тихо-соборова! [8, с. 4]; I день сонцеясний погаснув! [8, с. 7]; I від олжсиво-сонячної ери [8, с. 33]; недогавки плакатно-істеричні [8, с. 35].

Тонкий знавець народної мови, збирач і впорядник не одного словника крилатого українського слова, Віктор Антонович щедро використовує в поезії потужну силу фразеологізмів. Водночас автор вдається до трансформації фразеологізму: I пішли ви всі під три чорти 3 вашими КаПееСеСами й еСеСеРами! <...> [8, с. 42]; Весь світ об'ївся блекоти [8, с. 24]; пустили У вічі облуду-ману [8, с. 28]; Захаркай йому морду! [8, с. 34]; Не вімай, брате, вуха! [8, с. 34]; Заплюш на все очиці [8, с. 34]; контамінації: Та знайте, пам'яmaйте, що ваш глас - Горох, яким ударили об стінку $[8$, с. 58$]$; нагнітання фразеологічних одиниць: Він горя чашу вип'є повну вщерть, Усі його змагання підуть к бісу I всі надіï підуть шкереберть $[8$, с. 26]; Ви ж-куди повіє, В той бік $i$ гнетесь [8, с. 36]; Не дай себе, мій любий брате, Лихим людиям у шори вбрати - Припнуть край життєлетної дороги! [8, с. 41]. Фіксуємо також трансформацію афоризмів: I сум гіркий всевидящому Богу [8, с. 27]; Життя - то гра, а люди -то актори $[8$, с. 26]. Така експресія розрахована на мовне чуття слухача або читача, є каталізатором його думки, бо спонукає його до роздумів.

Особливим стилістичним колоритом відзначаються експресивні явища, що виникають через свідоме порушення словотвірних норм. На особливу увагу заслуговують оказіоналізми-новотвори, яким притаманні свіжість і несподіваність, структурно-дериваційне розмаїття.

У мовотворчій практиці В. Чабаненка переважають оказіоналізми, утворені за зразком продуктивних словотвірних типів із порушенням законів системної продуктивності. Характерною ознакою його ідіостилю є семантико-дериваційні оказіоналізми, утворені за допомогою пестливо-зменшувальних суфіксів від слів, що нормативно не піддаються афективності: іменники - загальні назви, топоніми, терміни: Ой моренько, ой горенько! $[8$, с. 5]; Ой, кароньки 3-за хмароньки [8, с. 5]; $3 a$ мученьку-розпученьку [8, с. 5]; Краӥнонько-Вкраӥнонько [8, с. 5]; Вічносте-мамо! Глянь же! Земелька твоя Тягне, Уже простягає до Хаосу ручки свої [8, с. 31]; Прудкі пегасики ускочать у клозети [8, с. 35]. Спираючись на давню народнорозмовну, а також фольклорну традицію, ці утворення породжують експресію ліризму або іронії і мають емоційно-оцінне значення.

В. Чабаненко є автором «потенційних» слів, тобто відсутніх у мові, але легко утворюваних за відомими словотвірними типами і моделями. Вони не порушують дериваційних норм, але їх не фіксують словники: Я вчора, мила, знову раював [8, с. 84]; I так мені розвеснено було, I так мені розкрилено летілось, I так мені стовічно жить хотілось [8, с. 84].

На відміну від експресивних явищ, пов'язаних iз нормами словотворення, експресивні явища, що виникають на грунті фонетичних / фонетико-орфоепічних норм сучасної літературної мови, у мовотворчості В. Чабаненка нечисленні. 3 виражально-зображальною метою використовується говіркова вимова звуків: Загортать харчі Хведоту, Як ітиме на роботу?! [8, с. 41].

Зібраний фактичний матеріал дозволяе відзначити, що експресивні явища, які постають на грунті морфологічних норм сучасної української літературної мови, спостерігаються лише в категоріях іменника. Найулюбленішими засобами $€$ використання множинної форми іменників власних назв. Водночас спостерігається семантичний зсув власного імені в бік загальності, метафоричності, символічності: Хрестами судними покрили Землю Лінчі [8, с. 23]; По торгах Юди совість рознесли [8, с. 23]; За щзо Пілати вас на муки віддавали? За що кати вас на Голготи виводжали? За щуо ицарі вас у Сибіри засилали? За щьо Нерони вас пекельно таврували? [8, с. 25]; Якби нараз воскресли всі пророки, Оті, щз їх потоплено у Tібрах, Оті, щзо їх замучено в Сибірах, Оті, щзо їх спалили в Орлеанах, Оті, що їх убили в Колізеях, Оті, щуо їх струїли в Бухенвальдах! [8, с. 26]; Дратують нас Ікари й Донкіхоти, Нас ваблять тихі стійла для худоби [8, с. 27]; I не ваблять мене орден, ані чин, Хай усе те зостається для Тичин, Що співають про артіль та маркізет. Я ж-торбешників співеиь, а не газет! [8, с. 75]; За якими дунаями Викликати тебе з ями? <...> [8, с. 10]. Такі засоби активізують образне асоціативне мислення читачів, впливають на почуття, формують оцінку суспільних явищ. Досить активно використовує автор порушення норми числа іменників загальних назв: Побуваю по всіх я світах $[8$, с. 2]; Упаду у твої запашні чебреці $[8$, с. 2]; Квиління, крики, стогони, плачі <...> [8, с. 23]; Скотилось вогниво утомлено згори, Смердючі багна гріти не схотіло [8, с. 29]; Своїм іудствам загубивши лік [8, с. 33]; Вони із пітьом вирвуться нараз [8, с. 69]. Зазначеними формами автор створює гіперболістично-узагальнювальні, метафоричні відтінки. Улюбленими засобами поета є відтворення заста- 
рілих відмінкових форм іменника: Хмари-мари літо вмерле В безвісти несуть [8, с. 18]; У ковилі засіли біля нор [8, с. 13], а також уведення в поезію розмовно-просторічних, говіркових форм дієслова: 3 гущави диха прохолода, Вербичкам коси розвіва. Шипиина он червоноплода Вдяга тонкі мережива [8, с. 21]; Ми в космос вікна відкриваєм, Братів по тюрмах убиваєм, - Мільярди в небо ми шпурляєм, Копійку тяжко заробляєм [8, с. 37]; Ми лиш про правду книги палим [8, с. 37].

Мовна експресія виникає i на грунті порушення автором синтаксичних норм: у вживанні ампліфікаційно-багатоступінчастої прикладки: Виє псом-блудягою-голоднягою [8, с. 25]; у повторенні сполучника, частки, вигука, прийменника: Називають нас бюрократами Тi, ще скучили вже, ой за гратами, Ой, за гратами ще й за мурами <..> [8, с. 36]; А кому потрібен дурень отакий, Що не крикне ані «слава!», ні «ура!»? [8, с. 75]; Я не хочу ні шани, ні слави, Ані почестей, ні нагород - Тільки б сяяли в вись злотоглаво Ті собори, щуо звів мій народ! [8, с. 75]; Де воркують i стогнуть, $і$ плачуть, I віщують любов голуби, $<\ldots>$ [8, с. 82]; Щоб наговоритись, Щоб намепотітись, Щоб одне до 'дного Ближче прихилитись [8, с. 86]; Бо він орг, усім товариш - I каліиі-жебракові, Й простачку-робітникові, I торбешнику з села $[8$, с. 36].

Отже, детальний аналіз фактичного матеріалу дозволяс зробити такі висновки. Найбільше стилістично маркованих відступів від норми спостерігаємо в лексиці, фразеології, словотворенні, менше - у морфології, ще менше - у фонетиці та синтаксисі.

Стилістичним колоритом відзначаються експресивні явища, які виникають на грунті порушення лексичних норм, що виявляється у вживанні просторіч, говіркових слів, корпоративного жаргону, сполучуваності слів. Активно використовує автор і потужний арсенал фразеології, вдаючись до трансформації фразеологізму (руйнування його зовнішньої або внутрішньої форми), контамінації фразеологізмів та нагнітання фразеологічних одиниць.

Експресивні явища на грунті порушення словотвірних норм виникають у разі використання автором оказіоналізмів-новотворів, серед яких переважають семантико-дериваційні оказіоналізми, утворені за допомогою пестливо-зменшувальних суфіксів від слів, що нормативно не піддаються афективності.

На відміну від експресивних явищ, пов'язаних із нормами словотворення, приклади експресіє, яка виникає на основі свідомого стилістично заданого відхилення автора від фонетичних / фонетико-орфоепічних норм літературної мови, у мовотворчості В. Чабаненка нечисленні.

Порушення зі стилістичною метою морфологічних норм у поезії В. Чабаненка спостерігаються лише в категоріях іменника: використання множинної форми іменників - власних назв, порушення норми числа іменників - загальних назв, уведення в поезію застарілих відмінкових форм іменника, відтворення розмовно-просторічних, говіркових форм дієслова.

Мовна експресія, що створюється автором через свідоме порушення синтаксичних норм, спостерігається в разі вживання ампліфікаційно-багатоступінчастої прикладки та повторів сполучника, частки, вигука, прийменника.

Естетична картина світу поета В. Чабаненка це вдале поєднання національного образного світобачення й філософського осмислення історичного процесу. Мовні засоби, залучені автором до творення образів ліричних творів, виявляють величезні потенції загальнонародної мови та неабиякі творчі можливості митця.

Досліджені стилістично вправні відступи від загальноприйнятих норм свідчать про мовну віртуозність автора, а манера їх використання накладає відбиток на його індивідуальний стиль, якому притаманні палкий патріотизм, глибока пошана до людини праці, захист цієї людини від різних соціальних утисків та несправедливості.

\section{ЛІТЕРАТУРА}

1. Кіраль С. Питання теорії і практики перекладу в епістолярній спадщині І. Денисюка, Г. Кочура, В. Чабаненка. Науковий вісник Національного університету біоресурсів та природокористування України. Філологічні науки. Київ, 2013. Вип. 186. Ч. 1. С. 102-113.

2. Микитів Г. Вербалізація концепту Нижньої Наддніпрянщини в поезії В. Чабаненка. Вісник Запорізького національного університету. Філологічні науки. 2013. № 3. С. 245-249.

3. Бацій І. Краса і сила слова. Київ : Радянська школа, 1983. 97 с.

4. Горбачевич К. Вариативность слова и языковая норма. Ленинград : Наука, Ленинградское отделение, 1978. 238 с.

5. Ермоленко С. Нариси з української словесності: стилістика та культура мови. Київ : Довіра, 1999. 432 с.

6. Пономарів О. Стилістика сучасної української мови. Київ : Либідь, 1993. 248 с.

7. Русанівський В. Естетика художнього слова. Культура слова. Київ : Наук. думка, 1976. Вип. 11. С. 5-17.

8. Чабаненко В. Січ духовна. Поезії. Запоріжжя, 2007. 220 с.

9. Чабаненко В. Стилістика експресивних засобів української мови : монографія. Запоріжжя : ЗДУ, 2002. $351 \mathrm{c}$. 


\section{REFERENCES}

1. Kiral S.S. (2013) Pytannia teorii i praktyky perekladu v epistoliarnii spadshchyni I. Denysiuka, H. Kochura, V. Chabanenka [Questions of theory and practice of translation in the epistolary heritage of I. Denisyuk, G. Kochur, V. Chabanenka] Scientific Bulletin of the National University of Life and Environmental Sciences of Ukraine. Philological Sciences. Issue 186. Part 1, pp. 102-113.

2. Mykytiv G.V. (2013) Verbalizatsiia kontseptu Nyzhnoi Naddniprianshchyny v poezii V.A. Chabanenka [Verbalization of the concept of the Lower Dnieper region in the poetry of V.A. Chabanenka] Bulletin of Zaporizhia National University. Philological Sciences. Zaporizhzhia : Zaporizhzhya State University. № 3, pp. 245-249.

3. Batsiy I.S. (1983) Krasa i syla slova [The beauty and power of the word]. Kyiv : Soviet School. 97 p.

4. Gorbachevich K.S. (1978) Varyatyvnost slova y yazykovaya norma [Word variability and language norm]. Leningrad : Nauka, Leningrad branch. 238 p.

5. Yermolenko S.Ya. (1999) Narysy z ukrainskoi slovesnosti: stylistyka ta kultura movy [Essays on Ukrainian literature: stylistics and culture of language]. Kyiv : Dovira. 432 p.

6. Ponomarev O.D. (1993) Stylistyka suchasnoi ukrainskoi movy [Stylistics of the modern Ukrainian language]. Kyiv : Lybid. 248 p.

7. Rusanivsky V.M. (1976) Estetyka khudozhnoho slova [Aesthetics of the artistic word] // Culture of the word. Issue 11. Kyiv : Naukova Dumka. Pp. 5-17.

8. Chabanenko V.A. (2007) Sich duhovna. Poezii [Spiritual Sich]. Zaporizhzhia : Dniprovsky metallurgist. $220 \mathrm{p}$.

9. Chabanenko V.A. (2002). Stylistyka ekspresyvnyh zasobiv ukrayinskoyi movy: Monografiya [The style of expressive means Ukrainian language]. Zaporizhzhia : Zaporizhzhya State University. 351 p. 